\title{
Removal of birch as a means of protecting raised bog mossy vegetation Ledo-Sphagnetum magellanici
}

\author{
Janusz Czerepko • Andrzej Boczoń • Michał Wróbel • Radosław Gawryś • \\ Karol Sokołowski
}

Received: 22 August 2016/ Accepted: 6 March 2018/Published online: 10 March 2018

(C) The Author(s) 2018. This article is an open access publication

\begin{abstract}
Raised bogs dominated by the vegetation association Ledo-Sphagnetum magellanici Sukopp 1959 em. Neuhäusl 1969 are a valuable and ecologically important plant community that occurs in Central Europe. They develop in impervious depressions with precipitation as the only water source, and are particularly sensitive to drainage, climate change, eutrophication and overgrowing by trees and shrubs. The high pressure of threat justifies taking protective measures. This research focused on the effects of the removal of birch from two bogs, which were dominated by two birch species (Betula pubescens, $B$. pendula) and also included stands of Scots pine (Pinus sylvestris); the bogs are located in northeastern Poland and showed signs of drying. The trees were removed in early spring 2008. To capture the response to tree cutting, vegetation monitoring was performed for 7 years. The results were compared to pre-cutting environmental conditions (precipitation, temperature, air transpiration). At the first site, which was drained at the beginning of the twentieth century, the ground water level initially decreased; then, from 2010 onwards, the level stabilised and exhibited a negative correlation with the average annual air temperature. While the second site exhibited no significant
\end{abstract}

J. Czerepko $(\bowtie) \cdot$ A. Boczoń · M. Wróbel ·

R. Gawryś · K. Sokołowski

Forest Research Institute, 3 Braci Leśnej St., Sękocin

Stary, 05-090 Raszyn, Poland

e-mail: j.czerepko@ibles.waw.pl differences in the ground water table, a correlation with the average annual rainfall was found. At both sites, there was an increase in the coverage of species appropriate for raised bogs, Oxycocco-Sphagnatea Br.-Bl. et R. Tx. 1943, whereas only the second site had significant coverage of these species. These actions improved the habitat conditions and initiated the process of raised bog restoration at that site because Oxycocco-Sphagnatea species cover and frequency increased.

Keywords Raised bog - Active protection . Vegetation succession · Piska forest · NE Poland

\section{Introduction}

Raised bogs dominated by the Ledo-Sphagnetum magellanici Sukopp 1959 em. Neuhäusl 1969 association develop in impervious depressions that are supplied with only rainwater. These raised bogs developed as a result of succession, which began during the last glaciation (Ellis and Tallis 2000; Dzhanelidze and Mikadze 2007). Raised bog mossy vegetation habitat is classified as a forest community despite being characterised by less than $50 \%$ woody vegetation cover (Czerepko 2008). The tree stand, which has a height of 5-10 m, is made up of Pinus sylvestris, with open crown cover. The understorey vegetation is dominated by species of shrubs, grass 
and peat mosses of the class Oxycocco-Sphagnetea (Aulacomium palustre, Andromeda polifolia, Drosera rotundifolia, Eriophorum vaginatum, Oxycoccus palustris, Sphagnum capillifolium, S. fuscum, S. magellanicum) and the class Vaccinio-Piceetea Br.-Bl. 1939 (Ledum palustre [dominant species], Pinus sylvestris, Pleurozium schreberi, Vaccinium myrtillus, $V$. uliginosum). Raised bogs are differentiated from Vaccinio uliginosi-Pinetum bogs because of an overwhelming preponderance of surface coverage by the species diagnostic class Oxycocco-Sphagnetea, including species of class Vaccinio-Piceetea (Matuszkiewicz 2007).

The Ledo-Sphagnetum magellanici raised bog is protected under the Natura 2000 network (http://ec. europa.eu/environment/nature/natura2000/index_en. $\mathrm{htm}$ ). It is part of habitat 7110 - a raised bog with peatforming vegetation, as included in Annex I of the Habitats Directive. The conservation status of this habitat in the continental region of Polish territory was defined as bad (U2). The main threats to this habitat include the exploitation of peat, drainage and alien vegetation succession (http://cdr.eionet.europa.eu; Navrátil and Navrátilová 2007; Soini et al. 2010; Jarašius et al. 2014; Konvalinková and Prach 2014). Important factors affecting raised bogs are nitrogen deposits (Akagi and Osawa 2005; Juutinen et al. 2010; Hurkuck et al. 2014) and climate change, which impact the amount of precipitation and transpiration (Mauquoy and Yeloff 2008; Minayeva and Sirin 2012). Protective projects have focused on improving water conditions by inhibiting the loss of water resources from the peatlands. Frequently, for the purpose of restoring peatlands, water outflows in the existing network of drainage ditches have been obstructed. Such procedures can have a rapid effect; the vegetation structure has been observed to shift, with a decrease in tree and shrub coverage. (Bönsel and Sonneck 2011; Dixon et al. 2014). However, the application of this type of action is not possible if the peatlands have not been previously drained and if the changes occurring on them are related to climate change, which includes a deficiency of precipitation and high air temperatures such that transpiration is enhanced (Glatzel et al. 2006; Lamentowicz et al. 2008; Van der Linden et al. 2008; Gałka et al. 2014). If it is not possible to implement damming, procedures limiting transpiration by removing highly transpiring plant species, which include trees, are thus recommended. Therefore, in many cases, restoration involves the removal of trees growing on raised bogs (Artz et al. 2013) to stop the succession and to increase soil moisture by reducing transpiration, which could encompass a significant share of the overall water loss (Schubert 2010; Fay and Lavoie 2009; Howie and Meerveld 2011). Although this method is quite frequently used, it generates questions about resulting impacts on vegetation, hydrology and soil conditions, and the general success of peatland restoration using this procedure (O'Brien et al. 2007; Stenild et al. 2010).

The unique hydrologic characteristics and plant community structure of peatlands must be addressed during restoration (Eiseltová 2010; Bönsel and Sonneck 2012). In addition, it is important to monitor sites for several years after project completion to assess the effectiveness of peatland restoration efforts (Erhenfeld 2001; Andersen et al. 2010; Rochefort et al. 2013).

The aim of this study was to evaluate the effectiveness of the removal of trees, saplings and birch undergrowth at raised bog sites exhibiting a drying trend resulting from climate change and artificial drainage.

\section{Materials and methods}

The study was conducted in northeastern Poland in the forest district of Strzałowo (Piska Forest) in the Mazury Lake District. The landscape of the area formed during the last glaciation (approx. 10,000 years ago); therefore, it is highly biodiverse.

Studies were carried out at two sites (B1 and B2) with an area of 1.47 and 1.91 ha spaced apart by approximately $3 \mathrm{~km}$ (N53.733980, E21.444791 and N53.730897, E21.492467) (Fig. 1). The depth of peat at site B1 reaches $10.5 \mathrm{~m}$ and is underlain with lake gyttja, whereas the peat at site B2 reaches $3.5 \mathrm{~m}$ in depth and is also underlain with lake gyttja. The presence of gyttja at the bottom of the peatlands indicates the presence of a kettle lake prior to bog development. All stages of peatland development have been found in the peat profile at both sites, indicating the process of succession consisting of vegetation filling in the lake, with gyttja deposits overgrown by low peat bogs followed by raised bogs with the LedoSphagnetum magellanici vegetation association. The structure of the raised bog mossy vegetation at the two 
Fig. 1 Location of sample plots at study sites B1 and B2

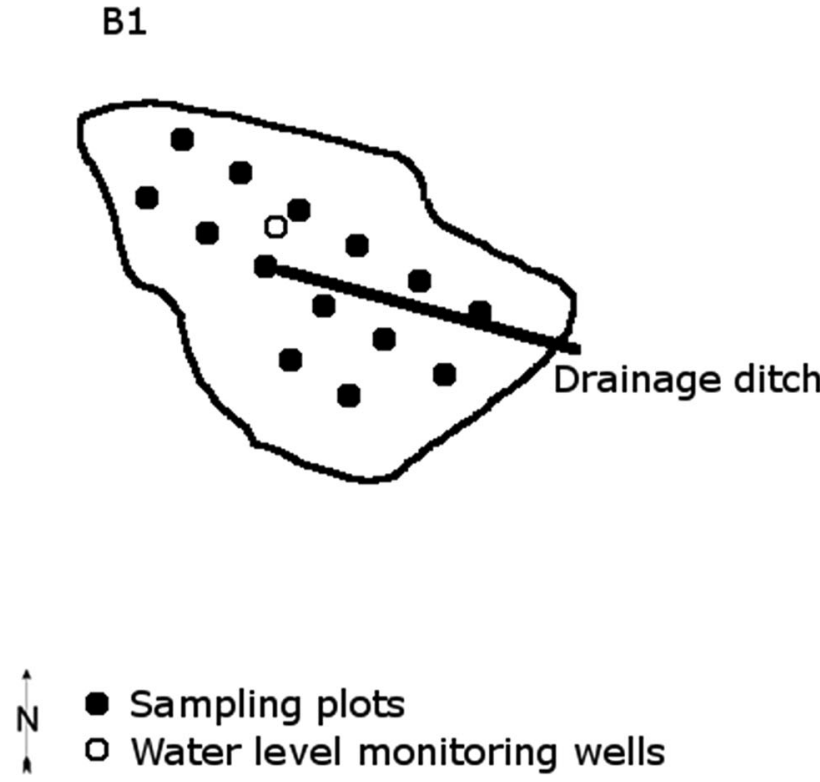

study sites shows characteristics of habitat drying. Over time, there has been an increase in the coverage of woody vegetation, especially birch (Betula pubescens and B. pendula), resulting in increased transpiration, a decline in cover/abundance of Norway spruce (Picea abies), and an increase in shading and provision of organic matter, which affects the trophic habitat conditions. Furthermore, site B1 is located in an old and overgrown drainage ditch constructed at about beginning of the twentieth century.

In March 2008 birch trees and undergrowth (trees less than $5 \mathrm{~m}$ high) and saplings at both sites were cut and removed by hand; pines, species that are typical of these raised bogs, were left. To capture changes of the surveyed raised bogs, vegetation monitoring and measurements of the water level were conducted. Measurements of the water level were carried out electronically by data loggers (Dataflow Systems Ltd) every $8 \mathrm{~h}$ from 2006 to 2013. On each area, there was one dipwell (perforated PVC pipe with $75 \mathrm{~mm}$ diameter). Vegetation monitoring was carried out before birch was removed in 2006 and then in 2008 and 2013 in circular sample plots, whose centres were located on the square grid plan at an interval of $25 \mathrm{~m}$ (Fig. 1). The area of a single circular study area was $100 \mathrm{~m}^{2}$, a sufficient sampling size for this type of community (Chytrý and Otýpková 2003). On each site 14 research sample plots were designated for monitoring changes in the vegetation. On the sample plots, phytosociological relevés were conducted (2006, 2008 and 2013) using the Braun-Blanquet (1964) method, with additional measurements of tree and shrub stem diameters at breast height (dbh), defined as the diameter $1.3 \mathrm{~m}$ above ground level. Ecological values as an average of plant indicators (light, soil trophic, soil acidity, soil humidity) were adopted according to Zarzycki et al. (2002), that is national equivalent of Ellenberg (1979) approach. Zarzycki's indicators are simple values from 1 to 5 , only moisture from 1 to 6 , for various abiotic factors. Mean values for these ecological numbers were calculated with a weighting to account for the level of percentage cover of the species present. The average value of the plot was calculated by weighting the metric with the percentage surface coverage of ground vegetation plant species. The summary percentage coverage of different groups of plant species was analysed (Braun-Blanquet 1964), and the individual plant species were classified into syntaxonomic groups on the basis of the Matuszkiewicz (2007) elaboration. The frequency values as the number of occurrence of species belongs to syntaxonomic groups in 14 sample plots in tree repetitions (2006, 2008, 2013) were presented also.

Precipitation totals for 2007-2013 (Fig. 2) were obtained from the meteorological station in Mikołajki, which is a $10 \mathrm{~km}$ distance from the research area.

To determine the sensitivity of the groundwater table to meteorological conditions, the monthly 


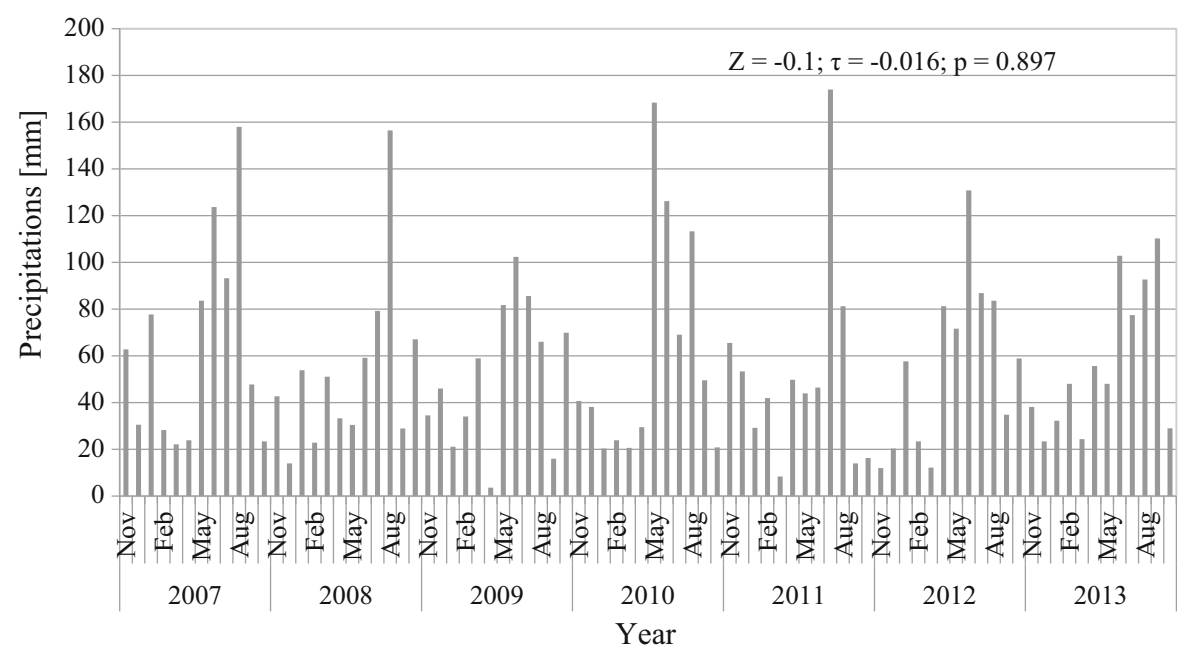

Fig. 2 The precipitation at the meteorological station in Mikołajki in years 2007-2013. The Seasonal Mann-Kendall test results $(Z, \tau$, p) are included in the figure

climatic water balance (CWB) was calculated as the difference between the total precipitation $(\mathrm{P})$ and the potential evapotranspiration (PET). The monthly evapotranspiration was calculated using the Ivanov formula (Bac 1968).

$\mathrm{EP}=0.00144(25+T) 2 \cdot(100-f)$,

where EP-monthly evapotranspiration potential (mm), $T$-average monthly air temperature $\left({ }^{\circ} \mathrm{C}\right), f-$ average monthly relative humidity of the air (\%).

This method has been applied in the absence of solar radiation measurements. The meteorological data from the Mikołajki weather station were used for the calculations.

Data time series as precipitation, evapotranspiration, water balance, ground water table were analysed using a non-parametric Seasonal Mann-Kendall test (Gilbert 1987), which is used to assess the importance of monotonic trends in hydrological and climatic characteristics (Douglas et al. 2000; Burn and Elnur 2002; Gemmer et al. 2004; Cannarozzo et al. 2006; Oguntunde et al. 2011). The data values were compared to all subsequent data values. The probability associated with the $Z$ test statistic was calculated. It was assumed that the trend was decreasing when the $Z$ was less than zero, and the probability was less than the adopted level of significance $\alpha=0.05$. The trend was considered to be increasing when $Z$ was greater than zero and the probability was less than the accepted level of significance $\alpha=0.05$. Strength and direction of the relationship between two variables were determined using a Kendall's tau coefficient $(\tau)$. Seasonal Mann-Kendall test and Kendall's tau coefficient were calculated using packages trend in $\mathrm{R}$ programme (Pohlert 2016).

The significance of the differences in the average height of the water table between the years was determined using a one-way analysis of variance (ANOVA) Tukey post hoc test, where $p<0.05$. The significance of the Spearman $r$ correlation coefficient between the average height of the water level and the average annual temperature and rainfall in different years was determined.

The significance of differences in the mean values covering individual strata of phytocoenosis, the number of species, the average sum of the coverage of groups of species and the ecological values at $p<0.05$ were determined using the Friedman test; then, to determine the differences between the post hoc ranks, a Friedman test with a Nemenyi amendment was used (Pohlert 2014).

\section{Results}

Water balance/climate trends

In the discussed period of 7 years of observations, the average annual precipitation at the meteorological station at nearby Mikolajki amounted to $676 \mathrm{~mm}$, with 
an average total of $460 \mathrm{~mm}$ in the summer and $216 \mathrm{~mm}$ in the winter. There were 3 years of above average rainfall and 4 years of below average rainfall during this time. The highest amount of precipitation occurred in 2007, and the lowest amount occurred in 2009 (Fig. 2). The year 2007 was characterised by high rainfall during the summer. Precipitation tended to decrease, although the decrease was not statistically significant (Fig. 2).

The average annual evapotranspiration in the described period amounted to $418 \mathrm{~mm}$ (Fig. 3), whereas in the summer months (May-October), it amounted to $312 \mathrm{~mm}$, and in winter (NovemberApril), it was $106 \mathrm{~mm}$. The highest evapotranspiration was recorded in 2009 and the lowest in 2013. Considering the monthly data, the highest evapotranspiration occurred in June 2008. The designated trend shows an decrease, but it was not statistically significant.

Based on these data, the values of the climatic water balance (Fig. 4) were calculated. There was a shortage of water during 21 months and an excess during 63 months. The greatest excess of water was recorded in May 2010 and in July 2011 due to high rainfall amounts. The largest water deficit occurred in April 2009. In the years 2007-2011, a few months of water deficit was observed. Between 2012 and 2013, there was a total of 3 months of water shortage; however, these values did not exceed $15 \mathrm{~mm}$. The data present no significant statistical changes.
Water level trends

The level of the ground water table at site B1 is illustrated in Fig. 5a. The elevation of the land where the measuring well was installed was $121 \mathrm{~m}$ above sea level (a.s.1.). During the 7 years of measuring the water level, it ranged from the 120.62 to $120.93 \mathrm{~m}$ a.s.l. The highest levels occurred at the beginning of the measurements, at the end of 2006 and the beginning of 2007 . The lowest water table level occurred in the summer of 2009, when the level dropped to $120.63 \mathrm{~m}$ above sea level, which is $37 \mathrm{~cm}$ below the ground surface. This was due to the low rainfall in this period, which was confirmed by the calculated balance (Fig. 3). Furthermore, the negative water balance had the effect of lowering the water table in 2011, when during 3 months of the year, the water level was $120.70 \mathrm{~m}$ a.s.l. The appointed trend was decreasing and statistically significant $(\tau=-0.262, p=0.005)$.

Changes in the water table level at B2 are shown in Fig. 5b. The ordinate of the measuring well amounted to $131.0 \mathrm{~m}$ above sea level. Water at this site stagnated on the surface for a certain period of time, notably in 2010 when the water balance indicated a water surplus. Fluctuations in the water table were contained in a range of $30 \mathrm{~cm}$. The maximum monthly average depth of stagnant water on the surface was $13 \mathrm{~cm}$. The lowest water levels were recorded at the end of the years 2009 and 2011. Then, they reached levels of

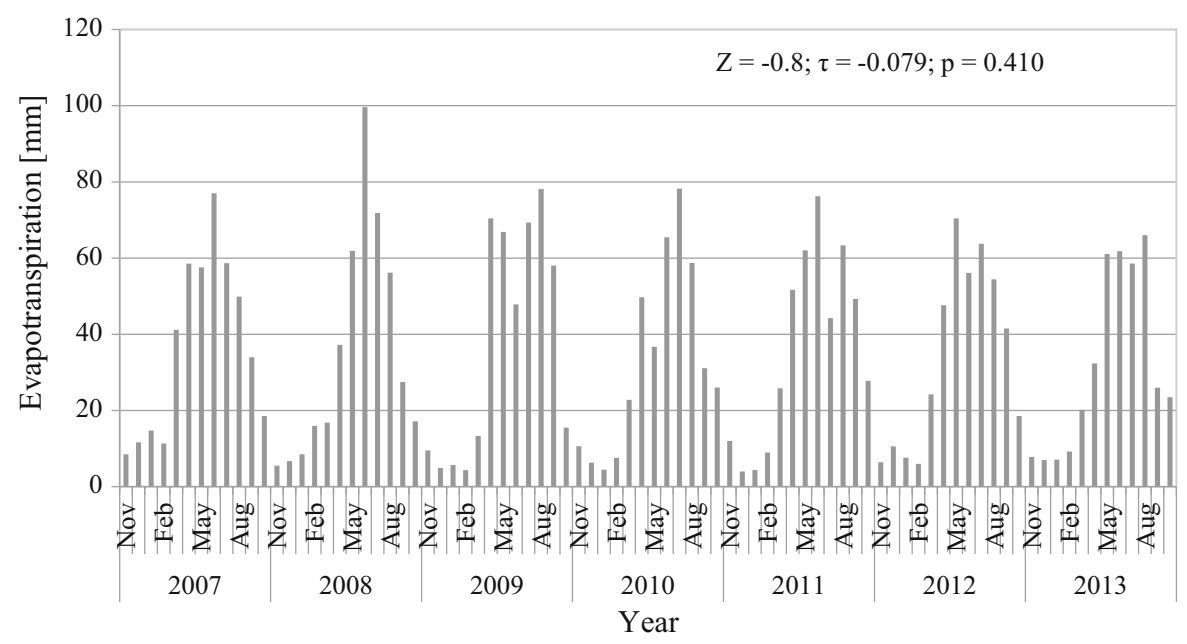

Fig. 3 The monthly averages of potential evapotranspiration according to data from a meteorological station in Mikołajki in years 2007-2013. The Seasonal Mann-Kendall test results $(Z, \tau, p)$ are included in the figure 


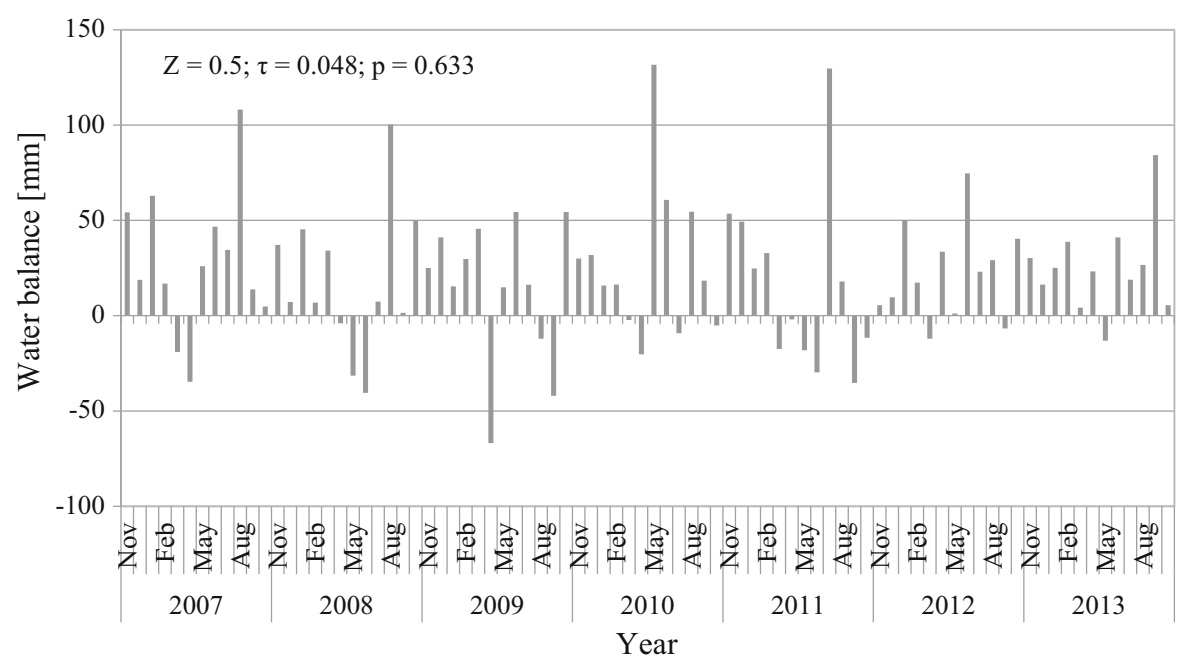

Fig. 4 Climatic water balance calculated from a meteorological station in Mikołajki in years 2007-2013. The Seasonal Mann-Kendall test results $(Z, \tau, p)$ are included in the figure

130.83 and $130.82 \mathrm{~m}$ a.s.l., respectively. The designated trend did not exhibit significant statistical changes.

The average level of the ground water table at B1 exhibited a negative correlation $(r=-0.33$, $p=0.001)$ with an average annual temperature and showed no correlation with the average annual rainfall $(r=0.04, p=0.717)$. At site B2, however, there was a positive correlation between the average height of the ground water table with the average annual rainfall $(r=0.28, p=0.015)$ and no correlation with the mean annual temperature $(r=0.09, p=0.400)$.

At site B1, the ground water level initially decreased; then, from 2009 onwards, it stabilised (Table 1). The difference between the first year of measurements before the tree cutting and the 2009-2013 years was statistically significant $(p=0.00004)$. While at site B2, no significant differences in the level of the ground water table were found in the analysed period.

\section{Plant community response to birch removal}

After the removal of birch in 2008, there was a rapid regeneration of this species at both sites (Table 2). Its number after 7 years was several times higher than before removal. An oak species (Quercus robur) moved onto site B1 following birch removal, and the number and basal area of this species increased over time. There was an initial decrease in the number of pines at this site, caused by the dieback of single trees, but the basal area of this species significantly increased. Spruce numbers at site B1 increased over the course of the study; at site B2, however, the spruce numbers decreased between 2008 and 2013. The number of pines did not change at B2.

At site B1, a significant increase was noticeable in the percentage cover of shrubs and undergrowth layer (Table 3), up to $29.6 \%$ in 2013. The coverage of trees, after artificial limitation of its coverage from $28.2 \%$ (in 2006) to $4.8 \%$ (2008), did not significantly increase in 2013. Coverage of the herb layer did not exhibit significant changes. Significant changes in the mosses and lichens layer were observed; this layer gradually increased the coverage from 59.6\% in 2006 to $65.7 \%$ in 2008. The total number of plant species, the number of tree and shrub species, and moss and lichen species numbers were significantly higher in 2013 compared to 2008 and 2006. Herbaceous plant species number increased significantly in 2013 compared to 2006. Significant changes in the ecological values were found (light, soil humidity and soil trophic indicator), but the statistical methods used did not allow for the indication of significant differences between years.

At site B2, the coverage of the tree layer in 2008 and 2013 remained at the same level (Table 3). While models indicated statistically significant differences in the layer of shrubs and of mosses and lichens, significant differences were not identified in pairwise comparisons between years. After reducing coverage 
(a)

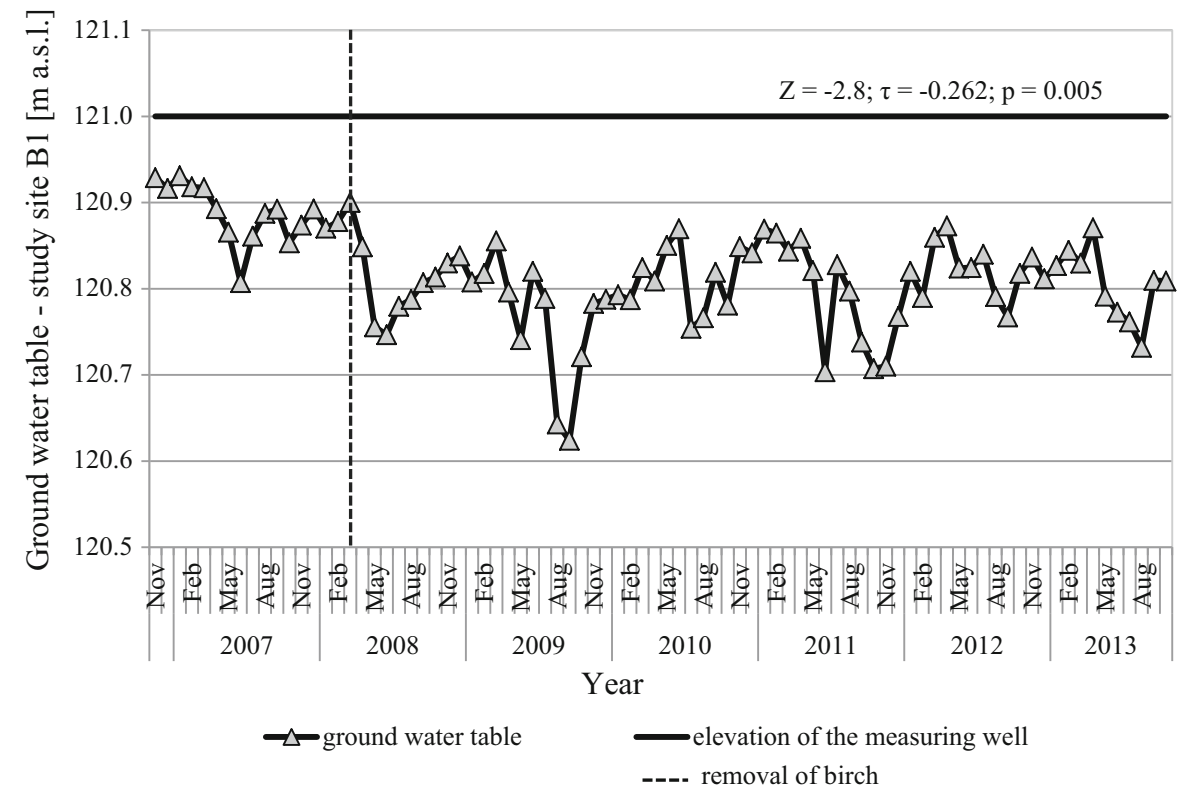

(b)

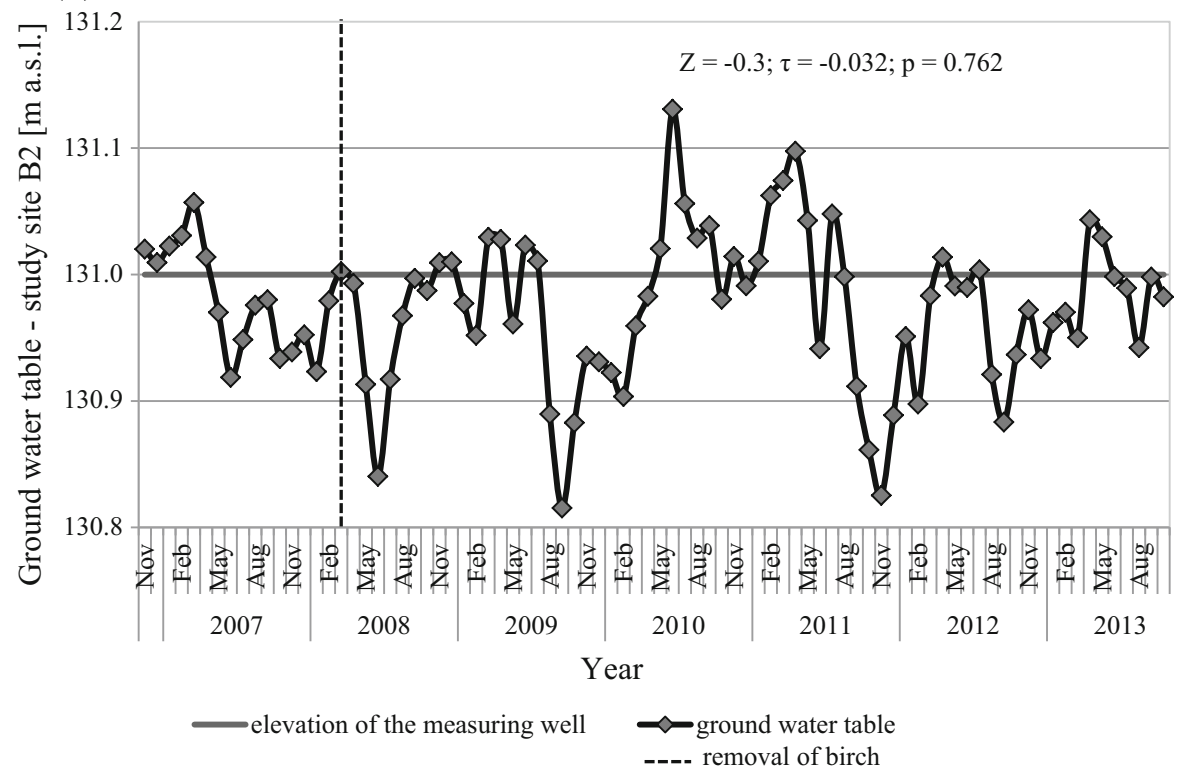

Fig. 5 Changes in the ground water table at study site B1 (upper graph) and B2 (lower graph) in hydrological years 2007-2013. The Seasonal Mann-Kendall test results $(Z, \tau, p)$ are included in the figure

in 2008, the shrub layer cover increased slightly in 2013. Moss and lichen coverage was equal in 2006 and 2008, but increased slightly in 2013. Similarly, the herb layer coverage was equal in 2006 and 2008 and insignificantly increased in 2013. There was a trend of increasing number of plant species from 15.4 in 2006 to 18.9 in 2013 , but the difference in the total number of species was significant only between 2006 and 2013. Mosses and lichen species numbers also showed a statistically significant increase. The number of herbaceous plant species per plot increased significantly from 2006 to 2008 and did not change in 2013. The number of species of trees and shrubs were equivalent in all 3 years. The value of the light 
Table 1 Average annual level of the ground water table at the B1 and B2 sites in the years 2007-2013
Mean of years having different letters are significantly different (oneway ANOVA, Tukey post hoc test, $p<0.05$ )

Table 2 Number of trees by species and basal area in 2006, 2008 and 2013 at two study sites in Piska Forest

\begin{tabular}{lll}
\hline Year & $\begin{array}{l}\text { Site B1 } \\
\text { Mean level of water table } \pm \text { SE } \\
p=0.00004\end{array}$ & $\begin{array}{l}\text { Site B2 } \\
\text { Mean level of water table } \pm \text { SE } \\
p=0.07560\end{array}$ \\
\hline 2007 & $120.889 \pm 0.011 \mathrm{a}$ & $130.990 \pm 0.012 \mathrm{a}$ \\
2008 & $120.829 \pm 0.016 \mathrm{ab}$ & $130.951 \pm 0.014 \mathrm{a}$ \\
2009 & $120.774 \pm 0.022 \mathrm{~b}$ & $130.966 \pm 0.020 \mathrm{a}$ \\
2010 & $120.802 \pm 0.010 \mathrm{~b}$ & $130.991 \pm 0.019 \mathrm{a}$ \\
2011 & $120.810 \pm 0.017 \mathrm{~b}$ & $131.004 \pm 0.020 \mathrm{a}$ \\
2012 & $120.807 \pm 0.013 \mathrm{~b}$ & $130.940 \pm 0.017 \mathrm{a}$ \\
2013 & $120.808 \pm 0.011 \mathrm{~b}$ & $130.981 \pm 0.010 \mathrm{a}$ \\
\hline
\end{tabular}

\begin{tabular}{|c|c|c|c|c|c|c|c|}
\hline \multirow[t]{2}{*}{ Site } & \multirow[t]{2}{*}{ Tree species } & \multicolumn{3}{|c|}{ Number of trees/ha } & \multicolumn{3}{|c|}{ Basal area $\left(\mathrm{m}^{2} / \mathrm{ha}\right)$} \\
\hline & & 2006 & 2008 & 2013 & 2006 & 2008 & 2013 \\
\hline \multirow[t]{4}{*}{ B1 } & Betula pendula and $B$. pubescens & 750 & 500 & 13,350 & 3.569 & 0.088 & 2.359 \\
\hline & Picea abies & 129 & 207 & 379 & 0.061 & 0.126 & 0.441 \\
\hline & Pinus sylvestris & 121 & 79 & 86 & 1.971 & 1.815 & 2.526 \\
\hline & Quercus robur & - & 7 & 21 & - & 0.001 & 0.004 \\
\hline \multirow[t]{3}{*}{ B2 } & Betula pendula and B. pubescens & 1029 & 414 & 11,736 & 2.318 & 0.073 & 2.074 \\
\hline & Picea abies & 7 & 43 & 7 & 0.014 & 0.046 & 0.001 \\
\hline & Pinus sylvestris & 7 & 7 & 7 & 0.472 & 0.472 & 0.472 \\
\hline
\end{tabular}

indicator significantly increased in 2013, as did the value of the moisture indicator for the same period. The indicator of soil acidity significantly increased from in 2008. The value of the trophic indicator also significantly decreased.

Several species common to the three main syntaxonomic species groups were identified at the study area (Table 4). At site B1, the dominant species of the coniferous forest syntaxonomic group of species of class Vaccinio-Piceetea (Table 5) demonstrated a trend, although not statistically significant, of increasing coverage and number of occurrences. In this group an increase in coverage was recorded for Vaccinium myrtillus, V. uliginosum, Calluna vulgaris and Ledum palustre. Species characteristics of the OxycoccoSphagnatea group had a higher number of occurrences compared to species of the Vaccinio-Piceetea group, but they had a lower coverage. Species of OxycoccoSphagnatea also exhibited steady growth and were more abundant than species in the Vaccinio-Piceetea group, and the number of occurrences and the average total coverage was significantly higher in 2008 and 2013 compared to 2006. The species, exhibiting the greatest increase in cover was Sphagnum magellanicum, which increased its coverage by $70 \%$ in 2013 to the value recorded in 2006 and 2008 (data not shown). Other species of this group that formed ground vegetation background (Oxycoccus quadripetalus, Eriophorum vaginatum) also exhibited an increase in coverage, but it was relatively small. Furthermore, a systematic increase in the number of occurrences was maintained in the analysed period by following species in the class Oxycocco-Sphagnatea: Aulacomium palustre (from 5 occurrences in 2006 to 13 in 2013), Polytrichum strictum (from 7 to 11), Andromeda polifolia (from 5 to 10), and Drosera rotundifolia (from 2 to 5) (data not shown). In 2013, for the first time, liverwort Cephalozia connivens was observed on 6 plots (data not shown). The species characteristics for fen and transitional peatlands in the group Scheuchzerio-Caricetea exhibited the smallest changes. It was slightly represented in undergrowth species composition compared to other selected syntaxonomic groups. The accompanying species (species not belonging to the groups identified) also exhibited no significant changes in coverage and occurrence. In 2008, an increase in the average value of the coverage sum and in the number of occurrences 
Table 3 Changes in the average covering layers of vegetation, the number of species and ecological indicators at the B1 and B2 sites

\begin{tabular}{|c|c|c|c|c|c|c|}
\hline \multirow[t]{2}{*}{ Features } & \multicolumn{3}{|l|}{ Year } & \multicolumn{3}{|l|}{ Difference } \\
\hline & 2006 & 2008 & 2013 & 2008-2006 & 2013-2008 & 2013-2006 \\
\hline
\end{tabular}

Site B1

Layer covers $(\%)$

\begin{tabular}{|c|c|c|c|c|c|c|}
\hline Tree** & $28.2 \pm 5.2$ & $4.8 \pm 2.5$ & $5.4 \pm 2.5$ & $-23.4^{*}$ & 0.6 & $-22.8^{*}$ \\
\hline Shrub** & $16.4 \pm 3.9$ & $16.1 \pm 4.1$ & $29.6 \pm 4.9$ & -0.3 & $13.5^{*}$ & $13.2 *$ \\
\hline Herb & $70.7 \pm 2.9$ & $69.3 \pm 2.9$ & $70.0 \pm 2.8$ & -1.4 & 0.7 & -0.7 \\
\hline Moss and lichen** & $59.6 \pm 7.7$ & $60.7 \pm 7.7$ & $65.7 \pm 6$ & 1.1 & 5.0 & 6.1 \\
\hline \multicolumn{7}{|c|}{ Number of plant species $\left(\mathrm{N} / 100 \mathrm{~m}^{2}\right)$} \\
\hline Total $* *$ & $15.6 \pm 0.6$ & $17.4 \pm 0.5$ & $22.2 \pm 0.9$ & 1.7 & $4.9^{*}$ & $6.6^{*}$ \\
\hline Tree and shrub** & $3.9 \pm 0.3$ & $4.0 \pm 0.2$ & $5.1 \pm 0.3$ & 0.1 & $1.1^{*}$ & $1.3^{*}$ \\
\hline Herb $^{* *}$ & $6.1 \pm 0.3$ & $6.4 \pm 0.3$ & $7.0 \pm 0.4$ & 0.4 & 0.6 & $0.9^{*}$ \\
\hline Moss and lichen** & $5.7 \pm 0.3$ & $6.9 \pm 0.4$ & $10.1 \pm 0.6$ & 1.2 & $3.1 *$ & $4.4^{*}$ \\
\hline \multicolumn{7}{|l|}{ Ecological indicators } \\
\hline Light** & $3.39 \pm 0.05$ & $3.41 \pm 0.05$ & $3.40 \pm 0.05$ & 0.02 & -0.01 & 0.01 \\
\hline Soil humidity** & $4.81 \pm 0.04$ & $4.81 \pm 0.03$ & $4.77 \pm 0.04$ & 0 & -0.04 & -0.04 \\
\hline Soil trophic** & $1.83 \pm 0.03$ & $1.83 \pm 0.03$ & $1.86 \pm 0.02$ & 0 & 0.03 & 0.03 \\
\hline Soil acidity & $1.95 \pm 0.03$ & $1.95 \pm 0.03$ & $1.98 \pm 0.02$ & 0 & 0.03 & 0.03 \\
\hline
\end{tabular}

Site B2

Layers cover $(\%)$

\begin{tabular}{|c|c|c|c|c|c|c|}
\hline Tree** & $10.0 \pm 4.2$ & $0.40 \pm 0.4$ & $0.40 \pm 0.4$ & -9.6 & 0 & -9.6 \\
\hline Shrub** & $22.9 \pm 3.9$ & $15.1 \pm 3.5$ & $18.6 \pm 2.9$ & -7.9 & 3.5 & -4.4 \\
\hline Herb & $69.3 \pm 0.7$ & $69.3 \pm 0.7$ & $70.0 \pm 0.0$ & 0 & 0.7 & 0.7 \\
\hline Moss and lichen** & $69.3 \pm 2$ & $69.3 \pm 2$ & $72.1 \pm 1.9$ & 0 & 2.9 & 2.9 \\
\hline \multicolumn{7}{|c|}{ Number of plant species $\left(\mathrm{N} / 100 \mathrm{~m}^{2}\right)$} \\
\hline Total** & $15.4 \pm 0.4$ & $17.0 \pm 0.5$ & $18.9 \pm 0.6$ & 1.6 & 1.9 & $3.5^{*}$ \\
\hline Tree and shrub** & $4.1 \pm 0.3$ & $4.3 \pm 0.2$ & $4.4 \pm 0.2$ & 0.2 & 0.1 & 0.4 \\
\hline Herb** & $6.4 \pm 0.2$ & $7.4 \pm 0.3$ & $7.4 \pm 0.4$ & $0.9 *$ & 0.1 & 1.0 \\
\hline Moss and lichen** & $4.9 \pm 0.3$ & $5.4 \pm 0.4$ & $7.1 \pm 0.5$ & 0.5 & 1.7 & $2.2^{*}$ \\
\hline \multicolumn{7}{|l|}{ Ecological indicators } \\
\hline Light** & $3.55 \pm 0.04$ & $3.56 \pm 0.05$ & $3.63 \pm 0.04$ & 0.01 & 0.07 & $0.08 *$ \\
\hline Soil humidity** & $4.65 \pm 0.02$ & $4.66 \pm 0.02$ & $4.71 \pm 0.03$ & 0.01 & 0.05 & $0.06^{*}$ \\
\hline Soil trophic** & $1.81 \pm 0.02$ & $1.80 \pm 0.02$ & $1.75 \pm 0.03$ & -0.01 & -0.05 & -0.06 \\
\hline Soil acidity** & $1.92 \pm 0.03$ & $1.91 \pm 0.03$ & $1.88 \pm 0.03$ & $-0.01 *$ & -0.03 & -0.04 \\
\hline
\end{tabular}

Significant differences between the means at $p<0.05$ based on the Friedman test are indicated as $* *$ for the given characteristic and as * between specific averages

of associated species was observed, but in 2013, there was a decline in their coverage and a greater number of occurrences. At this site, the only species that exhibited a significant change in coverage was Pohlia nutans, for which the coverage was significantly higher in 2013 compared to 2006 and 2008 (data not shown).
At site B2 prior to tree removal, the dominant ground vegetation coverage component consisted of species from the group Vaccinio-Piceetea (Pleurozium schreberi, Vaccinium myrtillus, Vaccinium uliginosum), but in 2013, raised bog species of the group Oxycocco-Sphagnatea began to play a dominant role (Table 5). Aggregate coverage for this group in 2013 
Table 4 List of species in the three syntaxonomic groups of species identified at the study area in Piska Forest, Mazury Lake District

\begin{tabular}{|c|c|c|c|}
\hline \multicolumn{4}{|c|}{ Syntaxonomic group of species } \\
\hline Oxycocco-Sphagnatea & Scheuchzerio-Caricetea & Vaccinio-Piceetea & Accompanying \\
\hline Andromeda polifolia & Calliergon stramineum & Bazzania trilobata & Brachythecium rutabulum \\
\hline Aulacomium palustre & Carex canescens & Dicranum polysetum & Calluna vulgaris \\
\hline Cephalozia connivens & Carex lasiocarpa & Dicranum scoparium & Cladonia coccifera \\
\hline Drosera rotundifolia & Carex nigra & Hylocomium splendens & Dicranum montanum \\
\hline Eriophorum vaginatum & Drepanocladus aduncus & Ledum palustre & Dryopteris carthusiana \\
\hline Oxycoccus quadripetalus & Sphagnum cuspidatum & Pleurozium schreberi & Galeopsis tetrahit \\
\hline Polytrichum strictum & & Trientalis europaea & Juncus effusus \\
\hline Sphagnum magellanicum & & Vaccinium myrtillus & Lepidozia reptans \\
\hline & & Vaccinium uliginosum & Molinia caerulea \\
\hline & & & Phragmites communis \\
\hline & & & Plagiothecium laetum \\
\hline & & & Pohlia nutans \\
\hline & & & Polytrichum commune \\
\hline & & & Polytrichum formosum \\
\hline & & & Rubus idaeus \\
\hline & & & Sphagnum fallax \\
\hline & & & Sphagnum palustre \\
\hline & & & Tetraphis pellucida \\
\hline & & & Veronica chamaedrys \\
\hline
\end{tabular}

Accompanying species are defined as species not belonging to the groups identified

Table 5 Changes in the frequency and the average value of the sum of coverage for the syntaxonomic group of species at the B1 and B2 sites in years 2006-2013

\begin{tabular}{|c|c|c|c|c|c|c|c|c|c|c|c|c|c|}
\hline \multirow[t]{3}{*}{ Site } & \multirow[t]{3}{*}{ Species groups } & \multicolumn{6}{|c|}{ Year } & \multicolumn{6}{|c|}{ Difference } \\
\hline & & \multicolumn{2}{|c|}{2006} & \multicolumn{2}{|c|}{2008} & \multicolumn{2}{|c|}{2013} & \multicolumn{2}{|c|}{ 2008-2006 } & \multicolumn{2}{|c|}{ 2013-2008 } & \multicolumn{2}{|c|}{ 2013-2006 } \\
\hline & & $F$ & $\operatorname{Cov}(\%)$ & $F$ & $\operatorname{Cov}(\%)$ & $F$ & $\operatorname{Cov}(\%)$ & $F$ & $\operatorname{Cov}(\%)$ & $F$ & $\operatorname{Cov}(\%)$ & $F$ & $\operatorname{Cov}(\%)$ \\
\hline \multirow[t]{4}{*}{ B1 } & Oxycocco-Sphagnatea & 60 & 36.6 & 74 & 38.8 & 87 & 44.3 & 14 & $2.2 *$ & 13 & 5.5 & 27 & $7.7 *$ \\
\hline & Vaccinio-Piceetea & 53 & 56.6 & 58 & 57.3 & 70 & 59.2 & 5 & 0.7 & 12 & 1.9 & 17 & 2.6 \\
\hline & Scheuchzerio-Caricetea & 14 & 1.9 & 15 & 1.9 & 17 & 1.9 & 1 & 0.0 & 2 & 0.0 & 3 & 0.0 \\
\hline & Accompanying & 38 & 40.7 & 40 & 41.1 & 67 & 38.9 & 2 & 0.4 & 27 & -2.2 & 29 & -1.8 \\
\hline \multirow[t]{4}{*}{ B2 } & Oxycocco-Sphagnatea & 54 & 36.8 & 57 & 38.6 & 59 & 49.5 & 3 & 1.8 & 2 & $10.9 *$ & 5 & $12.7 *$ \\
\hline & Vaccinio-Piceetea & 58 & 45.5 & 60 & 45.5 & 64 & 44.4 & 2 & 0.0 & 4 & -10.1 & 6 & -1.1 \\
\hline & Scheuchzerio-Caricetea & 10 & 0.1 & 23 & 0.2 & 31 & 0.2 & 13 & $0.1^{*}$ & 8 & 0.0 & 21 & $0.1 *$ \\
\hline & Accompanying & 36 & 41.6 & 38 & 41.6 & 49 & 50.2 & 2 & 0.0 & 11 & 8.6 & 13 & 8.6 \\
\hline
\end{tabular}

Significant differences between the means represented by individual years of observation at $p<0.05$ based on the Friedman test are indicated as *

$F$ number of occurrences in relevés, Cov average summary covering the group of species in the relevés (\%)

was significantly higher, by about $34 \%$ compared to 2006 and $28 \%$ compared to 2008 . The main species of undergrowth in the group Oxycocco-Sphagnatea were
Eriophorum vaginatum and Oxycoccus quadripetalus, and to a lesser extent Aulacomium palustre and Sphagnum magellanicum. For the first time in 2013, 
Polytrichum strictum appeared on 5 plots (data not shown). Andromeda polifolia appeared in two plots in 2006 and one plot in 2013 (data not shown). Species of group Vaccinio-Piceetea showed no statically significant change and remained at a similar level throughout the study period. Species of the group Scheuchzerio-Caricetea, which is characteristic of low and transitional peat bogs, gradually increased in both occurrence and coverage area, and this concerned mainly Eriophorum vaginatum and Oxycoccus quadripetalus, and to a lesser extent Sphagnum magellanicum. Statistically significant increases compared to 2006 in the coverage and occurrence of species from class Scheuchzerio-Caricetea were recorded in 2008 and 2013. During the 7 years of the study, there was a nearly threefold increase in the total occurrence and coverage by species of the class ScheuchzerioCaricetea; however, theses species were a minor vegetation component compared to the other vegetation classes. Accompanying species between 2006 and 2008 showed no major changes in terms of occurrence and coverage, and from 2008 to 2013 there was a statistically insignificant increase in occurrence and coverage.

\section{Discussion}

Contrary to expectations, the level of the ground water table did not increase at either site after birch removal, and at one of the sites (B1), it significantly decreased $(-7 \mathrm{~cm})$ and exhibited a downward trend. A decrease in the ground water table was observed in the first years after the procedure. This result is different compared to the findings of other authors, who found an increase in the ground water level after the removal of trees on peatlands (Sun et al. 2000; Xu et al. 2002). Conversely, afforestation may result in decreasing ground water table levels (Klimkowska et al. 2010) due to increased transpiration, and the rapid emergence of birch offshoots in reaction to cutting can have similar results (Stenild et al. 2010). Despite the strong recovery of birch in 2008 and 2013 as evidenced by increased tree numbers, birch basal area and coverage of trees and shrubs were lower compared to values prior to cutting. Thus, it can be assumed that the transpiration of woody vegetation did not have a key influence on the water balance of the two bogs. The presented study was limited, because there were no control sites on similar bogs where birch was not removed. Those control plots would have documented natural year-to-year variation in water table level. It was not possible, however, to find the control plots with the same site conditions. A positive, statistically significant correlation of changes in the position of the ground water table with an average annual rainfall in the site without a drainage ditch led, in turn, to the recognition of meteorological conditions as fundamental to the bog (Lamentowicz et al. 2008; Gałka et al. 2014). Lowering the groundwater level at site B1 (with the drainage ditch) in a situation with a stable climate footprint (P-ETP-PrecipitationEvapotranspiration) indicates that water flows from the site, even though the drainage ditch was old, uncured (not cleaned), shoaled (not deepened) and dominated by sphagnum mosses. Thus, it appeared to be clogged, but peat mosses formed a deep layer of acrotelm characterised by high water conductivity (Van der Schaaf et al. 2010). Outside the dome of the raised bog, a ditch runs through the low bog and is overgrown with alder currant Ribis nigri-Alentum Sol.-Górn. (1975) 1987, at this location the ditch is permeable and can drain water.

Site differences were observed in species composition changes after the removal of undergrowth and birch trees. At site B1 (with a drainage ditch), an increase in the coverage of raised bog species of class Oxycocco-Sphagnatea were observed, which were typical for the bog, but the aggregated coverage of species of this class was still lower than coniferous species of class Vaccinio-Piceetea. These changes were beneficial for the natural structure of the raised bog mossy vegetation (Matuszkiewicz 2007), but the moisture and mean light ecological indicators for the site were still unsatisfactory (Weltzin et al. 2003; Mauquoy and Yeloff 2008). At the same time, we identified an increase in Sphagnum magellanicum coverage by nearly $70 \%$; laboratory tests have indicated that this species can reduce temperature increases resulting from light (Weltzin et al. 2000). An additional further negative change at site B1 was indicated by the response of the tree stand. Both the fast regeneration of birch and an increase in the number of trees and diameter cross-sectional area of Pinus sylvestris, Picea abies, and Quercus robur suggest a decrease in the soil moisture (Vitas and Erlickytë 2007; Cedro and Lamentowicz 2011). 
At site B2, although the water table level did not change significantly in contrast to site B1, a change in vegetation promoting Ledo-Sphagnetum was observed. The positive effect connected with removing birch was an increase in the coverage of species appropriate for raised bog mossy vegetation of class Oxycocco-Sphagnatea. Thus, after 7 years the dominance of raised bog forest species indicates that typical raised bog mossy vegetation structure was restored (Sokołowski 1991). A lack of signs of desiccation in the substrate and a significant increase in the coverage ratio of raised bog mossy vegetation species, or in the soil humidity indicator, clearly show improvement in the substrate humidity conditions (see Weltzin et al. 2003; Mauquoy and Yeloff 2008). Improvement of water conditions deduced on the basis of environmental indicators was most likely the reason for the lack of such a strong regeneration of trees after the removal of birch compared to the site without a drainage ditchB1 (see Vitas and Erlickytë 2007; Cedro and Lamentowicz 2011). At the same time, exposing the substrate results in an increase in the value of the light indicator on the basis of a particular species of ground vegetation. Improvement in the water conditions as a result of this measure also had a negative effect on the mineralisation of organic matter (Glatzel et al. 2006), as shown by the trophic index value, which was significantly reduced at this site, contrary to site B1, where it increased. Changes in the trophic level stimulate the growth of birch saplings and undergrowth (Tomassen et al. 2004).

It can be assumed that the transpiration of woody vegetation at the two sites was not a key factor impacting site hydrology. Removal of birch increases the amount of light reaching ground vegetation, which favours the development of typical vegetation in peat bogs. However, the strong regeneration of birch trees quickly reduced the effect of the tree removal. Focusing active protection only on procedures to remove birch to restore the proper structure of tree stands to support raised bog mossy vegetation turns out to be insufficient and should be combined with blocking ditches that may drain the bog dome. As shown by these results and the work of other authors (Glatzel et al. 2006; Gałka et al. 2014), water conditions in rain-fed peat bogs depend primarily on the amount of precipitation. It should also be noted that the tree cutting procedure was carried out once. Strong tillering appearing in the next year could weaken the impact of the procedure. To see the real impact of woody vegetation on bog water levels, more cuts should be conducted, even several times a year, as recommended by Stenild et al. (2010).

\section{Conclusions}

Complete cutting to reduce the development of birch trees on a raised bog yielded better results at site B2, which did not have a drainage ditch. In the case of site B1, the removal of birch and saplings did not produce the desired effects. The reason for this may be a relatively short period of observation and the one-time execution of the procedure. Repeating the research in subsequent years, with more repetitions, may allow for verification of the effects of birch tree removal on a raised bog as a means of active protection.

Acknowledgements We would like to thank Mr. Andrzej Ryś from the Strzałowo forest district for offering his help in carrying out this research. The studies were made possible by funding from the Directorate-General of the State Forests in Poland, Grant No. BLP-299.

Open Access This article is distributed under the terms of the Creative Commons Attribution 4.0 International License (http:// creativecommons.org/licenses/by/4.0/), which permits unrestricted use, distribution, and reproduction in any medium, provided you give appropriate credit to the original author(s) and the source, provide a link to the Creative Commons license, and indicate if changes were made.

\section{References}

Akagi T, Osawa K (2005) Possible input of nitrogen of visitors' origin on a protected peatland. Environ Manag 35:461-467. https://doi.org/10.1007/s00267-003-0103-5

Andersen R, Rochefort L, Poulin M (2010) Peat, water and plant tissue chemistry monitoring: a seven-year case-study in a restored peatland. Wetlands 30:159-170. https://doi.org/ 10.1007/s13157-009-0015-0

Artz RRE, Donnelly D, Cuthbert A, Evans C, Smart S, Reed M, Kenter J, Clark J (2013) Restoration of lowland raised bogs in Scotland: Emissions savings and the implications of a changing climate on lowland raised bog condition. Technical Report, Commissioned by the Scottish Wildlife Trust

Bac S (1968) Studia nad parowaniem z wolnej powierzchni wodnej, parowaniem terenowym i ewapotranspiracją potencjalną. Studies of evaporation from the open water surface, field evaporation and potential evapotranspiration. Zeszyty Naukowe Wyższej Szkoły Rolniczej we Wrocławiu. Melioracja 13(80):7-68 (Polish) 
Bönsel A, Sonneck A-G (2011) Effects of a hydrological protection zone on the restoration of a raised bog: a case study from Northeast-Germany 1997-2008. Wetlands Ecol Manag 19:183-194. https://doi.org/10.1007/s11273-0119210-x

Bönsel A, Sonneck A-G (2012) Development of ombrotrophic raised bogs in North-East Germany 17 years after the adoption of a protective program. Wetlands Ecol Manag 20:503-520. https://doi.org/10.1007/s11273-012-9272-4

Braun-Blanquet J (1964) Pflanzensoziologie. Springer, Wien

Burn D, Hag Elnur M (2002) Detection of hydrologic trends and variability. J Hydrol 255:107-122. https://doi.org/10.1016/ S0022-1694(01)00514-5

Cannarozzo M, Noto LV, Viola F (2006) Spatial distribution of rainfall trends in Sicily (1921-2000). Phys Chem Earth 31:1201-1211. https://doi.org/10.1016/j.pce.2006.03.022

Cedro A, Lamentowicz M (2011) Contrasting responses to environmental changes by pine (Pinus sylvestris L.) growing on peat and mineral soil: An example from a Polish Baltic bog. Dendrochronologia 29:211-217. https:// doi.org/10.1016/j.dendro.2010.12.004

Chytrý M, Otýpková Z (2003) Plot sizes used for phytosociological sampling of European vegetation. J Veg Sci 18:563-570. https://doi.org/10.1111/j.1654-1103.2003. tb02183.x

Czerepko J (2008) A long-term study of successional dynamics in the forest wetlands. For Ecol Manag 255:630-642. https://doi.org/10.1016/j.foreco.2007.09.039

Dixon SD, Qassim SM, Rowson JG, Worrall F, Evans MG, Boothroyd IM, Bonn A (2014) Restoration effects on water table depths and $\mathrm{CO} 2$ fluxes from climatically marginal blanket bog. Biogeochemistry 118:159-176. https://doi. org/10.1007/s10533-013-9915-4

Douglas EM, Vogel RM, Kroll CN (2000) Trends in floods and low flows in the United States: impact of spatial correlation. J Hydrol 240:90-105. https://doi.org/10.1016/S00221694(00)00336-X

Dzhanelidze ZCh, Mikadze IP (2007) Stratigraphy and water supply conditions of the Kobuleti peat bog. Stratigrafiya. Geologicheskaya Korrelyatsiya 15:101-103. https://doi. org/10.1134/S0869593807040077

Eiseltová M (ed.) (2010) Restoration of lakes, streams, floodplains, and bogs in Europe. Wetlands: Ecology, Conservation and Management 3. https://doi.org/10.1007/978-90481-9265-6

Ellenberg, H. (1979) Zeigerwerte der Gefäszpflanzen Mitteleuropas. 2nd ed., Scripta Geobotanica 9, Göttingen

Ellis CJ, Tallis JH (2000) Climate control of blanket mire development at Kentra Moss, north-west Scotland. J Ecol 88:869-889. https://doi.org/10.1046/j.1365-2745.2000. 00495.x

Erhenfeld JG (2001) Defining the limit of restoration: the need for realistic goals. Restor Ecol 8:2-9. https://doi.org/10. 1046/j.1526-100x.2000.80002.x

Fay F, Lavoie C (2009) The impact of birch seedlings on evapotranspiration from a mined peatland: an experimental study in southern Quebec, Canada. Mires and Peat 5:article 3. http://www.mires-and-peat.net

Gałka M, Tobolski K, Górska A, Milecka K, Fiałkiewicz-Kozieł B, Lamentowicz M (2014) Disentangling the drivers for the development of a Baltic bog during the Little Ice Age in northern Poland. Quatern Int 328-329:323-337. https:// doi.org/10.1016/j.quaint.2013.02.026

Gemmer M, Becker S, Jiang T (2004) Observed monthly precipitation trends in China 1951-2002. Theor Appl Climatol 77:39-45. https://doi.org/10.1007/s00704-003-0018-3

Gilbert R (1987) Statistical methods for environmental pollution monitoring. Wiley, New York

Glatzel S, Lemke S, Gerold G (2006) Short-term effects of an exceptionally hot and dry summer on decomposition of surface peat in a restored temperate bog. Eur J Soil Biol 42:219-229. https://doi.org/10.1016/j.ejsobi.2006.03.003

Howie SA, Meerveld IT-V (2011) The essential role of the lagg in raised bog function and restoration: a review. Wetlands 31:613-622. https://doi.org/10.1007/s13157-011-0168-5

Hurkuck M, Brümmer C, Mohr K, Grünhage L, Flessa H, Kutsch WL (2014) Determination of atmospheric nitrogen deposition to a semi-natural peat bog site in an intensively managed agricultural landscape. Atmos Environ 97:296-309. https://doi.org/10.1016/j.atmosenv.2014.08. 034

Jarašius L, Matulevičiūtè D, Pakalnis R, Sendžikaite J, Lygis V (2014) Drainage impact on plant cover and hydrology of Aukštumala raised bog (western Lithuania) [Sausinimo itaka Aukštumalos aukštapelkès hidrologinems sąlygoms ir augalinei dangai]. Bot Lith 20:109-120. https://doi.org/ 10.2478/botlit-2014-0019

Juutinen S, Bubier JL, Moore TR (2010) Responses of vegetation and ecosystem $\mathrm{CO}_{2}$ exchange to 9 years of nutrient addition at Mer Bleue Bog. Ecosystems 13:874-887. https://doi.org/10.1007/s10021-010-9361-2

Klimkowska A, Dzierża P, Grootjans AP, Kotowski W, van Diggelen R (2010) Prospects of fen restoration in relation to changing land use-an example from central Poland. Landsc Urban Plan 97:249-257. https://doi.org/10.1016/j. landurbplan.2010.06.009

Konvalinková P, Prach K (2014) Environmental factors determining spontaneous recovery of industrially mined peat bogs: a multi-site analysis. Ecol Eng 69:38-45. https://doi. org/10.1016/j.ecoleng.2014.03.090

Lamentowicz M, Cedro A, Gałka M, Goslar T, MiotkSzpiganowicz G, Mitchell EAD, Pawlyta J (2008) Last millennium palaeoenvironmental changes from a Baltic bog (Poland) inferred from stable isotopes, pollen, plant macrofossils and testate amoebae. Palaeogeogr Palaeocl 265:93-106. https://doi.org/10.1016/j.palaeo.2008.04.023

Matuszkiewicz W (2007) A guide to plant communities of Poland. (Przewodnik do oznaczania zbiorowisk roślinnych Polski). PWN. Warszawa (Polish)

Mauquoy D, Yeloff D (2008) Raised peat bog development and possible responses to environmental changes during the mid- to late-Holocene. Can the palaeoecological record be used to predict the nature and response of raised peat bogs to future climate change? Biodivers Conserv 17:2139-2151. https://doi.org/10.1007/s10531-007-92222

Minayeva Yu, Sirin AA (2012) Peatland biodiversity and climate change. Biology Bulletin Reviews 2:164-175. https:// doi.org/10.1134/S207908641202003X

Navrátil J, Navrátilová J (2007) Wetlands succession in Ruda Nature Reserve, Czech Republic. In Okruszko et al. (eds) 
Wetlands: monitoring, modelling, management. Taylor \& Francis Group, London pp 27-36

O'Brien H, Labadz JC, Butcher DP (2007) Review of blanket bog management and restoration. Technical report to DEFRA. Project No. CTE0513

Oguntunde P, Babatunde A, Lischeid G (2011) Rainfall trends in Nigeria, 1901-2000. J Hydrol 411:207-218. https://doi. org/10.1016/j.jhydrol.2011.09.037

Pohlert T (2014) The pairwise multiple comparison of mean ranks package (PMCMR). R package

Pohlert T (2016). Trend: non-parametric trend tests and changepoint detection. R package version 0.2.0. https://CRAN.Rproject.org/package $=$ trend

Rochefort L, Isselin-Nondedeu F, Boudreau S, Poulin M (2013) Comparing survey methods for monitoring vegetation change through time in a restored peatland. Wetlands Ecol Manag 21:71-85. https://doi.org/10.1007/s11273-0129280-4

Schubert T (2010) Usuwanie drzew i krzewów na torfowiskach-jedna $\mathrm{z}$ metod czynnej ochrony torfowisk. Removing of trees and shrubs from mires - a method of an active mire conservation (abstract in english). Stud Lim Tel. 4:75-84

Soini P, Riutta T, Yli-Petays M, Vasander H (2010) Comparison of vegetation and $\mathrm{CO} 2$ dynamics between a restored cutaway peatland and a pristine fen: evaluation of the restoration success. Restor Ecol 18(6):894-903. https://doi. org/10.1111/j.1526-100X.2009.00520.x

Sokołowski AW (1991) Changes of the species composition of forest communities in nature reserves of the Białowieża Forest. (Zmiany składu gatunkowego zbiorowisk leśnych w rezerwatach Puszczy Białowieskiej). Ochrona Przyrody 49:63-78. (Polish)

Stenild J, Glerup K, Kjær S (ed.) (2010) Restoration of raised bogs in Denmark using new methods-a LIFE Project. Report is based on the results of the project and on the discussions at the national seminar on 9/10 September 2010. Danish Nature Agency. Conference proceedings

Sun G, Riekerk H, Kornhak LV (2000) Ground-water-table rise after forest harvesting on cypress-pine flatwoods in
Florida. Wetlands 20:101-112. https://doi.org/10.1672/ 0277-5212(2000)020[0101:GWTRAF]2.0.CO;2

Tomassen HBM, Smolders AJP, Limpens J, Lamers LPM, Roelofs JGM (2004) Expansion of invasive species on ombrotrophic bogs: desiccation or high $\mathrm{N}$ deposition? J Appl Ecol 41:139-150. https://doi.org/10.1111/j.13652664.2004.00870.x

Van der Linden M, Vickery E, Charman DJ, van Geel B (2008) Effects of human impact and climate change during the last 350 years recorded in a Swedish raised bog deposit. Palaeogeogr Palaeocl 262:1-31. https://doi.org/10.1016/j. palaeo.2008.01.018

Van der Schaaf S, van der Ploeg MJ, Vuurens SH, ten Heggeler MMJ (2010) Effects of drain blocking on the acrotelm of two raised bogs in the Irish midlands: a quantitative assessment. In Eiseltová M (ed) Restoration of lakes, streams, floodplains, and bogs in Europe wetlands: ecology, conservation and management, vol 3, pp 243-263. https://doi.org/10.1007/978-90-481-9265-6_13

Vitas A, Erlickytë R (2007) Influence of droughts to the radial growth of scots pine (Pinus sylvestris L.) at different site conditions. Balt For 13:10-16. https://doi.org/10.3176/eco. 2011.3.05

Weltzin JF, Pastor J, Harth C et al (2000) Response of bog and fen plant communities to warming and water-table manipulations. Ecology 81:3464-3478. https://doi.org/10.1890/ 0012-9658(2000)081[3464:ROBAFP]2.0.CO;2

Weltzin JF, Bridgham SD, Pastor J, Chen J, Harth C (2003) Potential effects of warming and drying on peatland plant community composition. Global Chang Biol 9:141-151. https://doi.org/10.1046/j.1365-2486.2003.00571.x

Xu Y-J, Burger JA, Aust WM, Patterson SC, Miwa M, Preston DP (2002) Changes in surface water table depth and soil physical properties after harvest and establishment of loblolly pine (Pinus taeda L.) in Atlantic coastal plain wetlands of South Carolina. Soil Tillage Res 63:109-121. https://doi.org/10.1016/S0167-1987(01)00226-4

Zarzycki K, Trzcińska-Tacik H, Różański W, Szeląg Z, Wołek J, Korzeniak U (2002) Ecological indicator values of vascular plants of Poland. Biodiversity of Poland 2. W. Szafer Institute of Botany, Polish Academy of Sciences, Kraków 